\title{
Böbrek Hastalıkları ve Lipit Metabolizması
}

\author{
Renal Diseases and Lipid Metabolism
}

\section{Mendane Saka ${ }^{1}$}

Geliş tarihi/Received: 01.03.2018 • Kabul tarihi/Accepted: 16.11.2018

\section{ÖZET}

Böbrekler, sıvı-elektrolit dengesinin kontrolü, kandan metabolik atıkları uzaklaştırılması, eritrosit yapımı, kan basıncının düzenlenmesi, kan hacmi ve pH’ının kontrol edilerek asit-baz dengesinin düzenlenmesinde rol oynar. Kronik Böbrek Yetmezliği (KBY) glomerüler filtrasyon değerinde azalmanın sonucu olarak böbreğin sıvı-solüt dengesi ile metabolikendokrin işlevlerinde kronik ve ilerleyici bozulma olarak tanımlanmaktadır. KBY'de epitelyal hasar, glomerül ve parietal bazal membran hasarı, arteriol ve kapiller damar duvarı kalınlaşması ve lümen daralması, glomerüllerde, tübülüslerde ve membranlarda skleroz, glomerüler filtrasyon hızında (GFH) azalma, nefronların tahribi gibi yapısal değişiklikler görülmektedir. Kronik böbrek yetmezliğinde, böbrek işlevlerinde azalma ile birlikte plazma lipit ve lipoprotein metabolizmasında, lipoproteinlerin hem miktar hem de kompozisyonunda ve apolipoproteinlerde (Apo) önemli değişiklikler oluşmaktadır ve anormal lipit metabolizması böbrek hastalarında yaygındır.

Anahtar kelimeler: Böbrek yetmezliği, lipit metabolizması, lipoprotein

\begin{abstract}
Kidneys play a role in liquid-electrolyte balance control, blood metabolic waste removal, erythrocyte production, blood pressure regulation, blood volume and $\mathrm{pH}$ control by controlling the acid-base balance. Chronic Renal Failure (CRF) is defined as a chronic and progressive deterioration in the metabolic-endocrine function of the kidney with fluid-solute balance as a result of a decrease in glomerular filtration value. In chronic renal failure, structural changes such as epithelial damage, glomerular and parietal basement membrane damage, arteriol and capillary vessel wall thickening and lumen narrowing, sclerosis in glomeruli, tubules and membranes, decrease in glomerular filtration rate (GFH), and nephron destruction are seen. In chronic renal failure (CRF), a reduction in renal function, plasma lipid and lipoprotein metabolism, both amount and composition of lipoproteins, and apolipoproteins, significant changes occur and abnormal lipid metabolism is common in kidney patients.
\end{abstract}

Keywords: Renal failure, lipid metabolism, lipoprotein

\section{GíRiş}

Kronik Böbrek Yetmezliği (KBY), glomerüler filtrasyon değerinde azalmanın sonucu olarakböbreğin sıvı-solüt dengesi ile metabolik-endokrin işlevlerinde kronik ve ilerleyici bozulma olarak tanımlanmaktadır. Epitelyal ve nefronların hasarı, arteriol ve kapiller damar duvar kalınlaşması ve lümen daralması, glomerüllerde, tübülüslerde ve membranlarda skleroz, glomerul filtratta azalma gibi böbrek işlev kaybı kritik bir

1. İletişim/Correspondence: Başkent Üniversitesi, Sağllk Bilimleri Fakültesi, Beslenme ve Diyetetik Bölümü, Ankara, Türkiye • E-posta: saka@baskent.edu.tr (1) https://orcid.org/0000-0002-5516-426X 
düzeye ulaştığında böbrek yetmezliği gelişmekte ve vücudun tüm organlarını etkileyen ciddi sonuçlar ortaya çıkmaktadır. Bu derleme makalede, böbrek yetmezliğinde lipit metabolizmasındaki değişim ve bu değişimin nedenleri incelenmiştir.

Normal insan böbreğinin toplam lipit içeriği yaş ağırlığının yaklaşık \%3’üdür. Bu miktarın yarıdan fazlasinı fosfolipit, 1/5'ni trigliserit (TG), 1/10'ini esterleşmemiş yağ asitleri oluşturur. Böbrek yakıt olarak çeşitli kaynakları kullanır. Yağ asitlerinin mitokondrial beta oksidasyonu renal adenozin trifosfat (ATP) üretimi için temel kaynaktır (1-3). Özellikle proksimal tübül yüksek enerji talebine, düşük glikolitik aktiviteye sahiptir. Serbest yağ asitlerinin (SYA) oksidasyonu renal oksijen tüketiminin yarısından fazlasından sorumludur. SYA plazmada albümin ile taşınır. Renal proksimal tüp reseptör aracılı albümin endositozu ile filtrattan albümine bağlı SYA alarak proksimal tübülde enerji dengesine katkıda bulunur (1). Proksimal tübül ayrıca vitamin gibi önemli lipofilik bileşikleri idrardan alarak lipoproteinler ile dolaşıma vermektedir.

KBY olan hastalarda anormal lipit metabolizması yaygındır. Böbrek işlevlerinde azalma ile birlikte plazma lipit ve lipoprotein metabolizması, lipoproteinlerin miktar ve kompozisyonu ile apolipoproteinlerde önemli değişiklikler oluşmaktadır (Tablo 1). Hastaların \%20-30’unda total kolesterol >240 mg/dL, \%10-45'inde düşük dansiteli lipoprotein (LDL) >130 mg/dL üzerindedir ve LDL'nin oksidatif modifikasyonu artmıştır. Yüksek dansiteli lipoprotein (HDL-K)'de ılımlı bir azalma vardır. LDL/HDL oranı ise artmıştır. KBY olan hastalarda postprandial şilomikron (\$̧M) artıklarının yüksek düzeyi belirlenmiştir (3-5).

Tablo 1. Böbrek hastalıklarında lipit ve lipoprotein anormallikleri (3)

\begin{tabular}{|c|c|c|c|c|c|}
\hline & KBY & NS & PD & HD & TH \\
\hline Total kolesterol & $\mathrm{N}$ veya $\uparrow$ & Belirgin $\uparrow$ & $\uparrow$ & $\mathrm{N}$ veya $\downarrow$ & $\uparrow$ \\
\hline TG & $\uparrow$ & Belirgin $\uparrow$ & $\uparrow$ & $\uparrow$ & $\uparrow$ \\
\hline LDL & $\uparrow$ & Belirgin $\uparrow$ & $\uparrow$ & $\mathrm{N}$ veya $\downarrow$ & $\uparrow$ \\
\hline \multicolumn{6}{|c|}{ LDL oksidasyonu $\uparrow$} \\
\hline HDL (HDL2) & $\downarrow$ & $\downarrow$ & $\downarrow$ & $\downarrow$ & $\mathrm{N}$ \\
\hline Non-HDL & $\uparrow$ & Belirgin $\uparrow$ & $\uparrow$ & $\mathrm{N}$ veya $\downarrow$ & \\
\hline Apo C-III & $\uparrow$ & & & & \\
\hline Apo A I ve A II & $\downarrow$ & & & & \\
\hline
\end{tabular}

KBY: Kronik Böbrek Yetmezliği, N: Normal, NS: Nefrotik sendrom, PD: Periton diyalizi, HD: Hemodiyaliz, TH: Trans hastası

KBY hastalarında lipoprotein lipaz (LPL), hepatik lipaz (HL) düzeyi ve LDL reseptörleri azalmıştır. $\mathrm{Bu}$ da oksidasyona duyarlı çok düşük yoğunluklu lipoprotein (VLDL), orta yoğunluklu lipoprotein (IDL) ve şilomikron artıklarının birikimine yol açmaktadır. Bu okside ürünler ise KBY hastalarında kardiyovasküler hastalı (KVH) patogenezinin gelişiminde rol oynamaktadır (3).

Kronik böbrek yetmezliği ve diyaliz hastalarında lipit metabolizmasına ilişkin primer bulgu hipetrigliseridemidir. Hipertrigliserideminin nedeni,
TG sentezinin artması, klirensin azalmasıdır. KBY insülin direncine (ID), İD ise hepatik VLDL üretiminde artışa ve VLDL klirensinde bozulmaya neden olur. Şilomikron (ŞM) klirensindeki bozulma ile de ŞM artıkları yükselir (3).

Hipertrigliseridemide, Apo C-III düzeyindeki artış, karaciğer tarafından şilomikron ve VLDL alımını baskılamakta, TG'den zengin ŞM ve VLDL lipoproteinlerinin yıkımı için gerekli lipoprotein lipaz (LPL) aktivitesini azaltmaktadır. KBY olan hastalarda hipertrigliserideminin diğer bir nedeni ise 
LPL'nin dolaşımdaki inhibitörünün (pre beta HDL) tutulumudur. $\mathrm{Bu}$ durum ise hepatik trigliserit (TG) düzeyini arttırırken, hepatik TG lipazın aktivitesini azaltmaktadır (3).

KBY hastalarında sıklıkla sekonder hiperparatroidizm gelişir. Bu durum lipit anormallikleri üzerinde etkiye sahiptir.KBYhastalarındaparatroidhormonyüksekliği hepatositlerde intraselüler kalsiyum düzeyinin artışı nedeni ile oluşmaktadır. KBY hastalarında LPL aktivitesindeki azalmaya, sekonder hiperparatroidizm karaciğer ve adipoz doku hücrelerinde kalsiyum (Ca) birikimini arttırarak katkıda bulunabilmektedir. KBY olan hayvan ve insan deneysel çalışmalarında paraidektomi yapılması ile serum TG düzeyi ve hepatik lipaz (HL) aktivitesinin normalize olduğu gösterilmiştir. HDL, antiinflamatuvar, antioksidan ve ters kolesterol sürecinde rol alan LDL oksidasyonunu önleyen bir lipoproteindir. HDL, TG zengin olgunlaşmamış ŞM ve VLDL için apolipoprotein (Apo A ve Apo C) sağlamaktadır. Bu ise TG metabolizması için önemlidir. Apo A1 ekstrahepatik dokulardan HDL-K aracılı kolesterol alımını sağlayan lesitin kolesterol açiltransferaz (LCAT) için gereklidir. LCAT kolesterolden fakir HDL-3'ün kolesterolden zengin HDL-2 olgunlaşmasında ve böylece HDL aracılı ters kolesterol taşınımında kritik rol almaktadır $(3,6,7)$.

Apo AII, karaciğerden HDL-K ile taşınan TG çıkarılmasında önemli olan HL aktivatörüdür. KBY, HDL-K'de işlevsel değişiklikler belirlenmiştir. Apo AI ve Apo AII azalmıştır. Bu durum üremik dislipideminin özelliğidir. Apo B içeren lipoproteinlerin birikimi düşük HDL-K düzeyi ile sonuçlanmaktadır. Periferik dokulardan serbest kolesterolün HDL-K taşınımına aracılıkedenalbüminşiddetliinflamasyondurumunda azalmakta ve hipoalbüminemi gelişmektedir (3).

Apo A-1 üretimindeki azalma (HDL-K düzeyinin azalmasına yol açar), lesitin kolesterol akil transferaz (LCAT) aktivite ve üretiminin azalmasina neden olmaktadır (HDL düzeyi ve HDL-K olgunlaşmasını azaltır). LCAT aktivite ve üretimindeki azalma kolesterol esterifikasyonunun azalmasına yani HDL ile birleşmede azalmaya yol açmaktadır. Üremik ratlarda plazma LCAT aktivitesindeki azalmanin nedeni hepatik LCAT gen ekspresyonunun azalması ile ilişkilidir. Kolesterol ester transfer protein (CETP) HDL'den kolesterol esterlerini orta dansiteli lipoprotein (IDL)'e transfer etmektedir. KBY'de CETP düzeyinin azalması HDL kolesterol esterinde azalmaya ve HDL'de TG düzeyinin artmasına neden olur. HL, HDL'deki TG hidrolizi ve uzaklaştırılmasını sağlar. HL yetersizliği HDL’nin TG içeriğini artmasına katkı sağlar. HL aktivitesi IDL partiküllerindeki TG hidrolizini katalizler ve LDL dönüşümünü sağlar. Kolesterolün intraselüler esterifikasyonundan sorumlu Asil CoA kolesterol asil transferaz (ACAT) aktivitesindeki artış HDL aracılı kolesterol alımını sınırlar ve plazma HDL kolesterolün azalmasına ve HDL olgunlaşmasının bozulmasına katkı sağlar (3).

Renal yetmezliği olan hastalarda glutatyon peroksidaz ve paraoksanaz enzim aktivitelerindeki azalma nedeni ile HDL'nin antioksidan ve antiinflamatuvar özellikleri bozulmuştur. Oksidatif stres disfonksiyonel HDL oluşumuna neden olur ve HDL proinflamatuvar etki gösterir. Disfonksiyonel HDL, KVH ve KVH mortalite riskindeki artış ile ilişkilidir. Hipoalbüminemi ile sonuçlanan proteinüri kolesterol biyosentezinin hız sınırlayıcı basamağı olan Hidroksi metil glutaril CoA redüktaz (HMG CoA) artışına ve hiperkolesterolomiye yol açar. Bu nedenle KBY olan hastalarda ağır proteinüri bu enzimin ekspresyonu ve aktivitesini değiştirebilir. Üriner protein kaybı ise karaciğerde LDL sentezini uyarır. LDL reseptör aracılı kolesterol alımı kolesterol dengesinde önemli rol oynar. KBY'de ağır proteinüri yok ise hepatik LDL reseptör gen ekspresyonu değişmez. Böbrek, lipit metabolizması için genellikle önemli bir organ sayılmaz. Çünkü glomerül filtrat bariyeri lipoprotein gibi büyük moleküllerin idrara filtrasyonunu önler. Ancak renal proksimal tüp, apolipoproteinler, albümin ve lipofilik maddeleri bağlayan proteinlerin alımı için reseptör ile donatılmıştır (7). 
Kronik böbrek yetmezliği ve son dönem böbrek yetmezliği (SDBY) olan hastalarda düşük serum kolesterol düzeyi ve mortalite artışı arasında ilişki belirlenmiştir. Düşük serum kolesterol düzeyi ile birlikte oluşan kötü prognozun malnütrisyon ve inflamasyona bağlı mortalitenin olumsuz sonuçlarını yansıttığı düşünülmektedir. Obezite ve hiperkolesterolomili diyaliz hastaları arasında hayatta kalımın arttığına ilişkin bulgular ortaya konmuştur. Protein-enerji malnütrisyonu (PEM) nedeni ile total kolesterol düzeyi normal, düşük ya da yüksek olabilir. Malnütrisyon/inflamasyon olmayan diyaliz hastalarında ise hiperkolesterolominin kardiyovasküler hastalık (KVH) mortalite artışı ile ilişkili olduğu belirlenmiştir. Tip 2 diabetes mellitus (T2DM) olmayan kronik böbrek hastalarında ise kolesterol düzeyi KVH mortalitesi ile ilişkili bulunmamıştır (3).

Karnitin, uzun zincirli yağ asitlerinin (UZYA) beta oksidasyonu için gereklidir. Yağ asitleri oksidasyon için sitozolden mitokondriaya taşınmak için önce yapısına CoA katılır ve aktiflenir. Mitokondri membranı CoA geçirgen değildir. Bu nedenle yağ asidinin asil CoA yapısındaki CoA yerine karnitin bağlanır, asil karnitin oluşur ve mitokondri membranını geçer. Asil CoA’nın asil Karnitine dönüşümü ile toksik asil grupları mitokondri dışına taşınmış olur. Serbest karnitin glomerüllerden filtre edilir ve $\% 90$ geri emilir. Asil karnitinin tübüler geri emilimi sınırlıdır ve asil karnitin klirensi serbest karnitine göre 4-8 kez fazladır. Klirens farklılıkları toksik asil gruplarının eliminasyonu için önemlidir. KBY'de hem asil hem serbest karnitin klirensi azalmıştır. Asil CoA birikimi İ, serbest radikal oluşumu, lipit peroksidasyonunun artmasına yol açar (8-10).

Amerika Birleşik Devletleri’nde Ulusal Böbrek Vakfı'nın Böbrek Hastalığı Sonuçları Kalite Girişimi (NKF-KDOQI: National Kidney Foundation Kidney Disease Outcomes Quality Initiative) ve Böbrek Hastalığı: Küresel Sonuçların İyileştirilmesi (KDIGO: Kidney Disease: Improving Global Outcomes) Açlık TG düzeyi >500 mg/dL hastalara tedavi edici yaşam tarzı değişikliklerini önermektedir. Bu öneriler diyet modifikasyonu, ağırlık kaybı, fiziksel aktivite artışı, alkol alımının azaltılması varsa hiperglisemi ve hipertrigliseridemi tedavisidir.

KDIGO ve NKF-KDOQI’e göre statin tedavisi:

- >50 yaş, glomerul filtrasyon hızı $(\mathrm{GFH})<45 \mathrm{~mL} /$ dakika/1.73 $\mathrm{m}^{2}$, diyalize girmeyen, $\mathrm{KVH}$ riski olup olmamasından bağımsız verilmelidir.

- <50 yaş, GFH<60 mL/dakika/1.73 m², KVH riski (sigara, diyabet ve proteinüri) yok ise statin tedavisi kullanılmamalıdır.

- 18-49 yaş arası diyalize girmiyor ve koroner hastalık, T2DM, iskemik inme, tahmini koroner ölüm insidansı 10 yll ya da ölümcül olmayan miyokard enfarktüs (MI) >\%10 olma gibi etmenlerden herhangi birine sahip ise statin tedavisi önerilmemektedir. Diyalize giren hastalarda lipit düşürücü tedavi kas toksisitesi ile ilişkilidir (11).

\section{SONUÇ VE ÖNERILER}

Kronik böbrek yetmezliğinin tüm aşamalarında lipit metabolizmasında anormallik oluşur. Hastalarda en yaygın dislipidemi hipertrigliseridemidir. Malnütrisyon nedeni ile total kolesterol yüksek, normal veya düşük olabilir. Düşük serum kolesterol düzeyi mortalite artışı ile ilişkilidir. $\mathrm{Bu}$ durum malnütrisyon ve inflamasyonun olumsuz etkisini yansıtabilir. Olgunlaşma sürecindeki bozulma nedeni ile düşük HDL düzeyi yaygındır. KBY’li hastalarda lipit anormallikleri ise KVH riskini arttırır (LDL-K, Lipoprotein (a), postprandial \$̧M artıkları ve LDL-K oksidasyonu artmıştır, HDL-K düzeyi düşüktür).

$\mathrm{Bu}$ hastalar $>50$ yaş, GFH $<45 \mathrm{~mL} /$ dakika/1.73 $\mathrm{m}^{2}$ diyalize girmiyor ise $\mathrm{KVH}$ risk etmenlerin olup olmamasından bağımsız statin tedavisi önerilir. Hastalar >50 yaş, $\mathrm{GFH}=45-59 \mathrm{~mL} /$ dakika/1.73 $\mathrm{m}^{2}$, diyalize girmiyor ve KVH risk etmenleri yok ise statin tedavisi yine önerilmektedir. Hastalar <50 yaş, GFH $<60 \mathrm{~mL} /$ dakika/1.73 $\mathrm{m}^{2}$ ve $\mathrm{KVH}$ risk etmenleri yok ise (sigara, diyabet, hipertansiyon, proteinüri) statin 
tedavisi kullanılmamaktadır. Böbrek hastalıklarında lipit kılavuzları üremik olmayan bireyler ile aynıdır. Enerjinin \%25-35’i yağdan ve bu yağın \%10'u çoklu doymamış yağ asidi (PUFA), \%20'si tekli doymamış yağ asidi (MUFA), <\%7 doymuş yağ asidinden (SFA) gelmelidir. Omega 6/omega 3 dengesi sağlanmalı (7/1), kolesterol <200 mg/dL, LDL düzeyi <100 mg/dL, TG $<500$ mg/dL olmalıdır. Dislipidemiyi azaltmak için 20-30 g posa (5-10 g çözünür posa) önerilmeli, beden kütle indeksi (BKI) ise $25-28 \mathrm{~kg} / \mathrm{m}^{2}$ arasında olmalıdır.

Çıkar çatışması - Conflict of interest: Yazarlar çıkar çatışması olmadığını beyan ederler. - The authors declare that they have no conflict of interest.

\section{KAYNAKLAR}

1. Bobulescua IL. Renal lipid metabolism and lipotoxicity. Curr Opin Nephrol Hypertens 2010;19(4):393-402.

2. Mount P, Davies M, Choy S W, Cook N, Power D. Obesity-related chronic kidney disease: the role of lipid metabolism. Metabolites 2015;5:720-32.

3. Pandya V, Rao A, Chaudhary K. Lipid abnormalities in kidney disease and management strategies. World J Nephrol 2015;4(1):83-91.
4. Trevisan R, Dodesini AR, Lepore G. Lipids and renal disease. J Am Soc Nephrol 2006;17:145-7.

5. Kwan B, Kronenberg F, Beddhu S, Cheung AK. Lipoprotein metabolism and lipid management in chronic kidney disease. J Am Soc Nephrol 2007;18:124661.

6. Vaziri ND. Dyslipidemia of chronic renal failure: the nature, mechanisms and potential consequences. Am J Physiol Renal Physiol 2006;290:262-72.

7. Vaziri ND. Causes of dysregulation of lipid metabolismin chronic renal failure. Semin Dial 2009;22(6):644-51.

8. Fouque D, Holt S, Guebre-Egziabher F, et al. Relationship between serum carnitine, acylcarnitines, and renal function in patients with chronic renal disease. J Ren Nutr 2006; 16:125.

9. Hoppel C. The physiological role of carnitine. In: L-Carnitine and Its Role in Medicine: From Function to Therapy, Ferrari R, DiMauro S, Sherwood G (Eds), Academic Press, London 1992; 5.

10. Schreiber BD. Debate forum: levocarnitine therapy is rational and justified in selected dialysis patients. Blood Purif 2006; 24:128.

11. Tonelli M, Wanner C. Lipid management in chronic kidney disease: synopsis of the Kidney Disease: Improving Global Outcomes 2013 clinical practice guideline. Ann Intern Med 2014;160: 182. 